\title{
Traditional Knowledge, Agave Inaequidens (Koch) Conservation, and the Charro Lariat Artisans of San Miguel Cuyutlán, Mexico
}

\author{
Ana G. Valenzuela-Zapata ${ }^{1}$, Irma Lopez-Muraira ${ }^{2}$, and Marie Sarita Gaytán ${ }^{3}$ \\ Authors' Addresses: ${ }^{1}$ Signo Tequila Foundation, ${ }^{2}$ Instituto Tecnológico de Tlajomulco, Tlajomulco de Zuñiga, Jalisco, Mexico, \\ ${ }^{3}$ University of Utah, United States \\ ana.valenzuela@gmail.com
}

Received: April $12^{\text {th }} 2011$

Volume: 2:72-80

Published: November $16^{\text {th }} 2011$

(C) 2011 Society of Ethnobiology

\begin{abstract}
The Mexican sport of charrería, or Mexican rodeo, developed in post-conquest Mexico as a way of preserving and celebrating traditional cowboy riding and livestock handling skills. Today, charrería is considered the national sport of Mexico and the charro (cowboy) is also a celebrated icon of Mexicanness. Special handcrafted ropes used in charrería, known as sogas finas, or charro lariats, are made from the fibers of the Agave inaequidens. The manufacture of charro ropes is an artisinal practice that requires both cultural and botanical knowlege. In the last ten years, there has been a significant decline in the $A$. inaequidens population in the Cerro Viejo mountain range of the central-western Mexican state of Jalisco, putting the financial wellbeing of local lariat artisans at risk. Drawing on fieldwork and laboratory analysis conducted from 2002 through 2010, we discuss the socio-cultural significance of charro lariats, detail the harvesting of $A$. inaequidens in relation to lariat craftsmanship, document the physical characteristics of the $A$. inaequidens from this region, and describe the relationship between traditional knowledge and the local economy. The goal of this research is two-fold: 1) to stimulate feedback between producers and consumers in an attempt to leverage the existing business cluster based on traditional knowledge and 2) to initiate dialogue concerning conservation, domestication, and sustainable management of the wild $A$. inadequidens population.
\end{abstract}

Key Words: Agave inaequidens, Hard Fibers, Plant Conservation, Charro Lariat

Introduction

In 2002, farm technicians in San Miguel Cuyutlán, a small town in the western state of Jalisco (Figure 1), reported a decrease in the wild population of $A$. inaequidens Asparagaceae Koch in the surrounding Cerro Viejo Mountains. A. inaequidens is the primary raw material used by lariat artisans (sogueros) to make charro lariats (reatas de ixtle or sogas finas), the ropes central to the popular Mexican sport of charerría (Mexican rodeo).The local craftsmen depend on this population of agave because it cannot be substituted with sisal and/or henequen, which are fibers made from two different agave species, $(A$. sisalana Agavaceae Perrine, henequen $A$. fourcroydes Asparagaceae Lem) or other synthetic materials for $A$. inaequidens fibers. Since 2006, producers, researchers, and the local government have been working on $A$. inaequidens seed propagation and reforestation. While some progress has been made in cultivating the species, it is unclear whether or not the fiber quality will remain the same. ${ }^{1}$ In this article, we document the traditional knowledge associated with the art of charro lariat craftsmanship and address issues pertaining to the conservation of $A$. inaequidens in the Cerro Viejo mountain range.

At least 200 families in the region support themselves by harvesting, extracting, and transforming by hand the long, shiny agave fibers into charro lariats. The relative economic success of this traditional craft reduces the need for labor-induced emigration from communities in the region. However, the wild populations of the once abundant $A$. inaequidens have diminished at the same time that the demand for charrería apparel in Mexico and the United States has increased. As a consequence, the financial wellbeing of lariat artisans is being threatened during a period when they should potentially be making greater profit. What explains the disappearance of the native $A$. inaequidens? As we illustrate, this pheomenon is a result of a combination of factors that include disease, deforestation, and inexperienced agave fiber harvesters. The goals of this research are two-fold: 1) to stimulate feedback between producers and consumers in an 


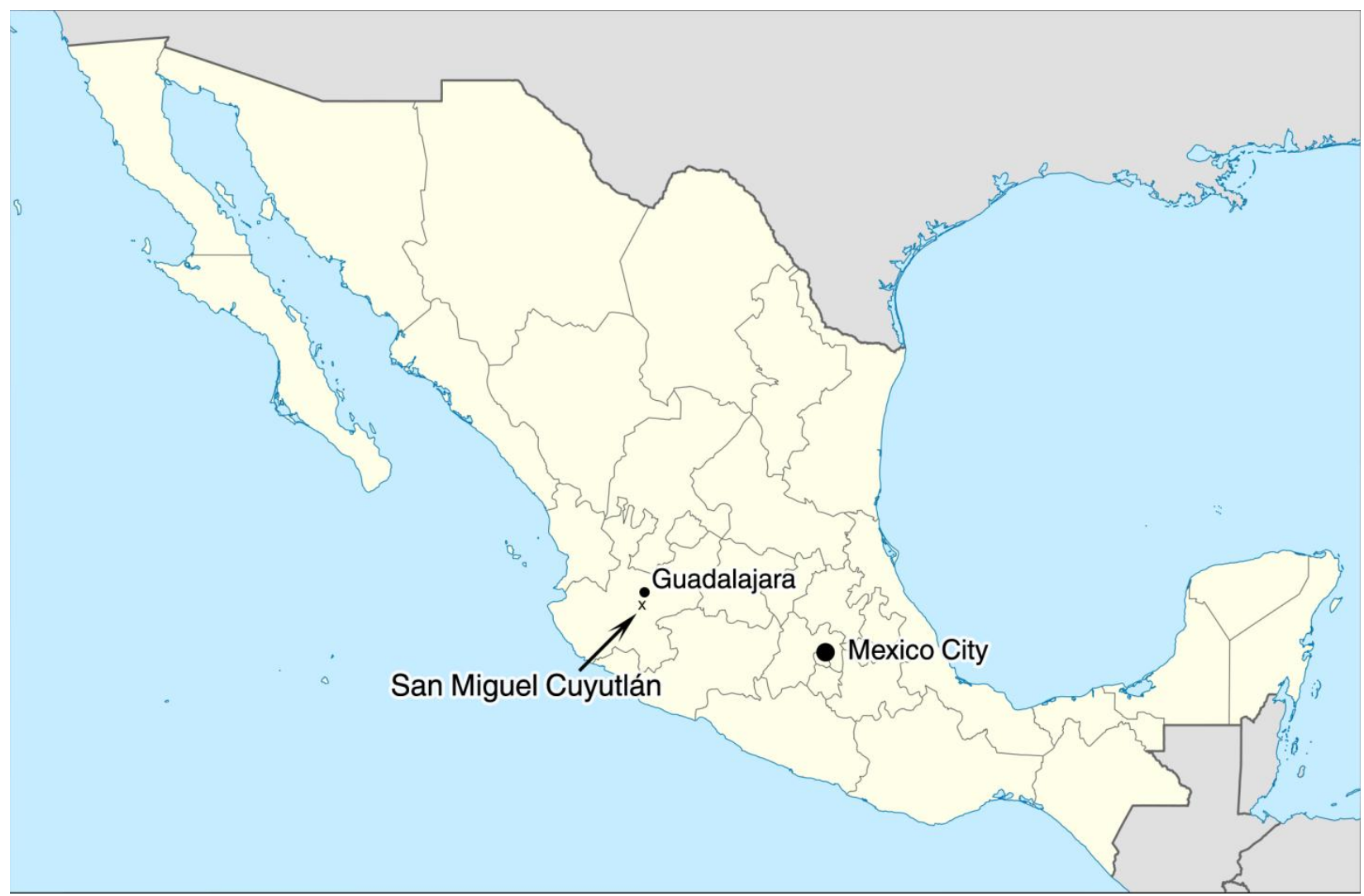

Figure 1: Map of Mexico showing the location of San Miguel Cuyultán in Jalisco.

attempt to leverage the existing business cluster based on traditional knowledge and the local economy and 2) to initiate dialogue concerning conservation, domestication, and sustainable management of the wild $A$. inadequidens population.

\section{Methods}

In 2006-2007, we held a total of four focus group meetings at lariat-making workshops with fiber harvesters (ixtleros) to explore the role of traditional knowledge in relation to cultural, economic, and sustainability matters. Each focus group was comprised of six to eight men and discussions addressed themes including agave harvesting, the diminishing numbers of A. inadequidens, lariat making, and the artisans' concerns for their families and their communities. Each focusgroup meeting lasted roughly two hours and segments of each gathering were video recorded. ${ }^{2}$

We also attended ten lariat-making workshops at two charreria schools: The Colomos School of Charrería, in Guadalajara, the state capital of Jalisco and Lienzo Charro in Tlajomulco de Zuñiga, a town just southeast of Guadalajara. As participant observers at numerous charreadas (charro sporting events) in Jalisco, we took field notes and recorded video of the various lariat techniques used throughout each competition. In November 2007, we conducted interviews with rope artisans in Coatepec Harinas near Mexico City, another location where $A$. salmiana Asparagaceae Otto ex Salm fibers are harvested. In total, from 2002-2010, we conducted 38 semistructured interviews with individuals involved in the production and use of charro lariats (15 ixtleros and crafters, 3 farm technicians, 20 charros and lariat sellers).

Botanical explorations were carried out from 2002 to 2007 in sites where field harvesters collect agave in the Cerro Viejo lowlands mountain region of Tlajomulco de Zuñiga and San Miguel Cuyutlán. Specimens were prepared with labels detailing the date, locality, plant description (with or without flowers), and leaf-length measurement. The specimens were later taken to the Technological Institute of Tlajomulco herbarium. With the technical assistance of several 
different harvesters, we collected agave specimens of different ages, both with and without flowers. The species were identified according to the principles outlined by Gentry (1982).

\section{Study Area}

San Miguel Cuyutlán is located at $20^{\circ} 20^{\prime} \mathrm{N}$ by $103^{\circ} 14^{\prime}$ $\mathrm{W}$ in the municipio of Tlajomulco in the state of Jalisco in western Mexico. Wild $A$. inaequidens populations in Cerro Viejo (CV) are found in oak forests with Quercus laurina Fagaceae Bonpl., Q. rugosa Fagaceae Née, Q. candicans Fagaceae Née, and Q. obtusata Fagaceae Humb. and Bonpl. (González 1986). The agave flourishes at high elevations on open rocky slopes associated with oak, pine-oak and pine-oyamel (Abies sp.) forests. It is also found in tropical deciduous forests (Vázquez-García et al. 2008).

\section{Study Limitations}

Our initial findings suggest that two forms of agave correspond to the same species, $A$. inaequidens. However, due to the limitations we describe below, we cannot make taxonomic categorizations with regard to subspecies or varieties of the same taxon. Since species of the Agave genus are monocarpic and perennial, botanical studies and studies of agave biology must be long term if they are to obtain flowering specimens and to identify the new taxon. ${ }^{3}$ This limitation is even more severe when wild populations are overexploited. With so few specimens actually in flower, we were unable to write full descriptions of all the plants' organs in the wide and narrow-leaved $A$. inaequidens we found. The joint limitations of having to find specimens in flower, and the long periods between flowering, meant we had to wait a long time to find samples where all the plants' characteristics could be observed and identified as species or varieties. Therefore, we call attention to the need for more research that draws on both conventional and biomolecular botanical methods.

Other limitations were related to our interactions with informants. In particular, we found that lariat artisans were reluctant to talk to us about their traditional techniques for fear that they might be copied and reproduced in China. Additionally, there was scant and sometimes contradictory information provided regarding costs and income because the artisans were concerned about tax issues.

\section{Results}

Background: The Mexican Sport of Charreria

Charrería, or Mexican rodeo, is a uniquely Mexican cultural tradition involving technical equestrian skills associated with cattle ranching that can be traced to the arrival of the Spanish in the fifteenth century. In addition to prompting drastic changes to the religious, political, and social lives of local populations, colonization introduced many new foods, traditions, and animals to the "New World." One such animal was the horse. Initially only elite men were permitted to own horses, but as cattle ranching began to develop, lower class mestizos were allowed to work in teams of men on horseback (Nájera-Ramírez 1994). On the open range, charros (hombres a caballo or jinetes) refined and perfected their horsemanship skills. The growth of the hacienda system with large landed estates created a demand for workers who could "break wild horses, feed and breed cattle, control bulls and broncos, and protect the cattle and themselves from the dangers of the range" (Nájera-Ramírez 1994:2). Training and controlling animals required tools, such as thin ropes known as mecates, which were specifically designed for the ranching conditions of the Mexican range.

Over the years, ranch workers adapted new saddle styles, riding, and roping techniques. In the 19th century, haciendas began to host public events for charros to compete and to demonstrate their horsemanship skills. When the economic significance of the hacienda system began to decline after the Mexican Revolution (1910-1920), so too did the need for charros. Whereas charros once played a significant material role in the Mexican economy, they were slowly becoming more recognized for their athletic and artistic capabilities (LeCompte 1985). In 1921, the National Association of Charros was established to preserve and promote the cultural traditions associated with charrería. In 1933, Mexican President Abelardo Rodriguez formally declared charrería the national sport of Mexico. Today, there are more than 900 charro organizations in Mexico and the United States (Palomar 2004).

\section{The Lariat in Charreria Culture}

The contemporary charreada, or the main event associated with charrería culture, consists of competitions and also features food, live music, and dance performances. Each charreada begins with a short opening ceremony in which competing teams parade their horses around the arena. Once finished, the participants take their places for the first of nine demonstrations in ten events. A major component of the events involves the charros' demonstration of his technical and artistic handling of the lariat. The lariat is the charros' most important tool, and, unlike other equestrian sports, is an essential piece of equipment. In fact, charrería has its own specialized vocabulary 
Table 1: Charro Events and Characteristics of Lariat Use

\begin{tabular}{|c|c|c|c|}
\hline Event & Resistance to tension & Resistance to friction & $\begin{array}{c}\text { Floreo variants/bonus } \\
\text { points }\end{array}$ \\
\hline $\begin{array}{l}\text { Fore-footing on foot and on } \\
\text { horseback }\end{array}$ & Important & Less important & Very important/12 \\
\hline Fore-footing from horseback & Important & Important & Very important/10 \\
\hline Roping the hind legs & Important & Very important & Important \\
\hline Team bull roping & Important & Less important & Very important/13 \\
\hline
\end{tabular}

Source: The authors, with data from charrería scoring rules.

related specifically to rope use. For example, chorrear la soga (spray the rope) means to slip down out of the saddle while roping and catching the animal. Today, much of this vocabulary is formally used in the specifications of events. Table 1 shows the charro events which require the use of the lariat. Below are a few examples of the events that feature lariat components.

1. Piales (Hind foot roping) consists of stopping a mare going out the gate, galloping along the track, being roped by the hindquarters by a charro mounted on a horse.

2. Ternas (Team bull roping) consists of three roping charros on horseback working as a team who must rope a bull, hobble it (rope it and catch it by the feet) and bring it down. They may use lariats, or other material to rope the feet of the animal.

3. Manganas (Forefooting) The charro, starting at least four meters from the edge of the ring, after flourishing his lariat, ropes the forequarters of the horse, who begins to run, having been driven by three mounted charros. Once it is forefooted (its forefeet tied), the charro pulls on his lariat to bring it down.

3.1. Manganas a Pie (Horse catching on foot) The charro positions himself in the arena and an untamed horse is guided to a run by three mounted teammates. The charro artistically twirls his lariat accumulating points in a display of skilled trick roping maneuvers and timing. He then throws a loop and attempts to catch the horse's forelegs. ${ }^{4}$

3.2 Manganas a Caballo (Foreleg horse catching from horseback) This event follows the same sequence as manganas a pie, except that it is conducted on horseback.

Charros are also judged by their abilities to perform the floreo (flowering of the lariat or flourishing a fancy rope) in which they maneuver the lariat in a wave-like pattern and execute revolutions or spins. Each of the various floreo movements has a name, such as "change," "mirror," "spring," and so on. The rules give precise definitions for scoring, bonus points, disqualifications, time limits for each events, and infractions.

\section{The Ropes of San Miguel Cuyutlán}

Charro lariats evolved from conventional rope (mecate) made from agave fibers (ixtle). Over time, fiber harvesters (ixtleros), rope makers (sogueros), and charros improved on the basic design to make it more suitable for roping and handling horses and cattle in charreada competitions. Once implemented, the modifications were systematized, and according to the charros we talked to, the changes added significantly to the artistic and technical level of sophistication central to handling the lariat. Both charros and charrería scholars described the best quality ropes as those made of ixtle. (Dean and Rodriguez 2003); of those made of ixtle, ropes from San Miguel Cuyutlán (which are known as coyotlanas in charro slang), were identified as having the best reputation. Charros preferred ropes from this town because of their better flexibility, strength, and color. Further, the ropes are widely considered to cut the best figures, to produce the best performances, and to yield the most points when used in competition by professional charros (Dean and Rodriguez 2003).

From Mesoamerican Ropes to Charro Lariats

Writing from an anthropological perspective, Saumade (2008) contends that early ropes were used for hunting and as weapons in ancient Mesoamerican society. Beyond solely serving a material purpose, they were also symbolically significant. In particular, ropes were closely linked to family lineage (marriage, children, and blood ties) and also reflected the duality of the sexes, whereby men were symbolized by the rope itself and 
women were reflected in the circular forms of the manipulated rope. This gendered symbolism carries on today in charrería, and ropes are closely associated with masculinity. For example, in Mexico, if someone is very manly or is good at something he is described as a lariat (reata). Also, "to handle a lariat" has sexual overtones in relation to catching someone in a compromising sexual position (Islas Escárcega 1992). Another popular expression, "Lariat knowledge spare me, the lariat is all I need (Lazar me sobra, reata es lo que me hace falta), refers to an individual who has the knowledge or ability to complete a challenging task, but lacks the proper equipment or tools to carry it out; in charro slang, it also refers to demonstrating one's sexual prowess. Further, ropes and lariats are commonly used in expressions to describe physical attractiveness. For example, a "good rope" (una buena reata) could describe an attractive woman.

Charro rope appears in official charrería guidelines as a wardrobe element without any description. In VIII article chapter 57 of the 2011 Charro rulebook (Charrería Reglamento 2011), charro attire and charrería regulations are described in detail; however, there is no mention of charro ropes.

Charros prefer ixtle or lechuguilla ropes because they work well in performances. Soguillas (leather ropes) and paraffine-coated cotton are well suited in humid and hot regions respectively. In the past, generic names as ixtle and lechuguilla have resulted in incorrect botanical identification of agave fibers. Ixtle refers to fibers from Agave lechuguilla Torr. Agavaceae Hutchinson, Yucca carnerosana Agavaceae (Trel.) McKelvey, Y. filifera Chabauud Agavaceae Hutchinson, and Aechmea magdalenae Bromeliaceae (André) André ex Baker (Garcia-Moya and Ayala-Sosa 2007). The term lechuguilla is registered by Colunga-GarciaMarin et al. (2007) to name the following Agavaceae species: $A$. zebra Gentry, $A$. angustiarum Trel., $A$. angustifolia Haw., A. atrovirens Karw. ex Salm-Dyck, $A$. aurea Brandegee, A. bovicornuta Gentry, $A$. cantala (Haw.) Roxb. ex SalmDyck, A. fortiflora Gentry, A. funkiana K. Koch \& C.D. Bouch, A. gigantesis Gentry, A. kerchovei Lem, A. lechuguilla Torr., A. lophanta Schiede, A. maximiliana Baker, A. maximiliana var . Katherinae Gentry, $A$. palmeri Engelm, $A$. peacockii Croucher, A. scabra Gentry, $A$. schotii Engelm $A$. shrevei Gentry, and A. sobria (Trel.) I.M. Johnst. A. lechuguilla is the most important hard fiber plant from central and northern arid areas in Mexico (Reyes-Agüero, Aguirre, and Peña 2000) but it is not adequate for charro ropes.

According to the charros we interviewed, the agave fiber ixtle (from A. inaequidens and A. salmiana) is irreplaceable because of the specific conditions and attributes developed by the formal structure of charrería as a sport. Earlier versions of ropes used by professional charros were much thicker than their current counterparts, changing from 36 wires to one with a heart (central wire) to 6 wires (Miranda 1993). Rope thickness was one of many changes that took place as charrería evolved in the early part of the twentieth century (Palomar 2004). Specifically, the ropes became thinner as charros' roles changed from exclusively working on haciendas (e.g., breaking horses) to taking on more showmanship qualities (e.g., competing in rodeos).

\section{Taxonomy and Agave Fibers}

The Agave genus is the most diverse genus of the Agavaceae family. Of some 200 species in the New World, $150(75 \%)$ are found in Mexico with 69\% endemism (Garcia-Mendoza 2002). Today there are primarily four uses for agave: as fibers, as aguamiel (sap), as pulque (fermented sap), and as mezcal or tequila (distilled from the cooked and pressed juices of agave) (Valenzuela and Nabhan 2004). In the last ten years, scholars have made important inroads with regard to documenting the agricultural diversity of the Agave genus in Mexico. Specifically, there are many botanical studies on the agave species used in the distillation of tequila and mezcal (Colunga-GarciaMarín et al. 2007), while less is known about the agaves used in pulque or for fibers. From an economic perspective, fibers made of henequen ( $A$. fourcroydes and $A$. lechuguilla) are the most important, but research on these plants has diminished in the last several years. Otherwise, agave species are currently attracting renewed interest for their ability to produce biomass for biofuel production in non-irrigated marginal land (Nobel 2010; Valenzuela 2011).

Today, wild and native species of the Agave genus are used for fiber and handicrafts mainly by indigenous communities. In the northern state of Sonora, indigenous groups utilize $A$. jaiboli Gentry and $A$. angustifolia Haw. (Yetman and Van Devender 2002) and in the southern state of Oaxaca they use: Agave americana $\mathrm{L}$. var americana, $A$. americana var oaxacensis Gentry, $A$. angustiarum Trel., $A$. angustifolia var angustifolia Haw., A. angustifolia var rubescens Gentry, $A$. convallis Trel., and $A$. horrida Lem. ex Jacobi Hutchinson (Garcia-Mendoza 2004).

Agave inaequidens in Cerro Viejo

The $A$. inaequidens plant grows in volcanic soils on cliffs and ravines of the Sierra Madre Occidental and the Trans-Mexican Volcanic Belt (Gentry 1982) and is the 
primary raw material for mezcal (Valenzuela et al. 2008) and raicilla (a type of mezcal made from $A$. lechuguilla) (CONABIO 2005).

Like other species of the Crenatae group (Gentry 1982), they have interbred, and are plants with medium to large rosettes, which rarely reproduce asexually by rhizome or axillary shoots. Their main characteristic is their deeply crenate and mammillated leaf margins. This study also reports for the first time on the importance of the specificity of $A$. inaequidens, section Crenatae use in the tradition of handcrafted charro ropes and details their unique attributes for their use in charrería competitions.

Herbarium materials and field observations show that $A$. inaequidens grows in two forms in Cerro Viejo: wide leaves and dense inflorescences, and narrow leaves and sparse inflorescences, the latter perhaps an effect of selection. The plants are in anthesis in winter and fruits and flowers are picked in February.

\section{Handcrafting Cluster in San Miguel Cuyutlán}

A. inaequidens grow wild on the rocky volcanic slopes of the Cerro Viejo Mountains (2960 m) about an hour out of the city of Guadalajara on the highway to Colima. The fibers are extracted from the leaves, and the sap left after the fibers are stripped is used to prepare cancer remedies. The floral axes are roasted for food, and the flowers, which are eaten by deer, are used as bait by hunters. Some agave fiber harvesters (ixtleros) stated that aguamiel (a drink prepared from the sap) used to be extracted from these plants, but during the study period, no aguamiel was seen being sold in the region. Aguamiel is obtained by cutting the central cone of leaves and carving out the base to collect the sap that runs down from the leaves by the force of gravity.

Approximately 200 families in San Miguel Cuyutlán earn supplemental income by harvesting fiber and making rope. This region of Jalisco is known for its wood and fiber, its kitchen tools made of volcanic rock, and its metal-working crafts. The production of ropes in Cuyutlán is a localized production system in which fiber harvesting and collecting, rope production, and charrería all take place around the Cerro Viejo Mountain region. The area has considerable emigration and the main source of income is from family members working in the United States.

A rope production unit is composed of a master rope maker, who knows the entire process, and two apprentices. Only men are rope makers. Each unit has its own shed and area for hanging ropes, but up to five units may share a plot of land, splitting the cost of renting the lot. Sales are mainly local and within Mexico, but consumption of these products is beginning to increase in the United States as charreria becomes more popular. Rope crafters sell to charros, small-scale merchants, and specialized stores, several of which are on the internet. They also sell their ropes at charreadas.

\section{Agave Harvesters and Traditional Knowledge}

The ixtlero selects, harvests, and extracts the fiber. He uses three tools: a board (tabla), a knife (raspador), and a pocket knife (cuchilla) to cut up the leaf and strip the fibers. The ixtleros have traditional, particular skills pertaining to how to select and harvest plants. Specifically, they have intimate knowledge of the process of picking and stripping the leaves and removing the fibers and the post-harvest treatment. In addition, they know how to protect and evaluate wild populations and the fiber quality.

\section{Harvest}

We measured the best leaf dimensions preferred by collectors in a sample $(\mathrm{n}=4)$ of the best plants chosen for harvest by ixtleros. To find one plant whose leaves are suitable for picking, an ixtlero must walk at least one hour, and in general it takes a full 8-hour working day to obtain 6 leaves, the quantity that will yield $1 \mathrm{~kg}$ of fiber. Plants are harvested for the first time (the leaves are not cut off, but detached) when they are 5-7 years old. The agaves which are used are about 7 years old, and after one year they produce around 6 leaves, and fewer the next year. A plant may be harvested three times and it is then left to flower. We believe that it is for this reason that wild semi-domesticated populations growing in forest clearings have the most fiber.

\section{Stripping}

After the leaves have been detached, the edges are cut to make them easier to handle and strip. The leaf is placed on a stone and beaten with a stick to soften the texture. The leaf is then placed on a plank made from avocado wood (Persea gratissima Lauraceae Mill) and tied in place, and the fibers are stripped with a pocketknife. This task must be done very carefully to avoid cutting the fibers, which are 1 to 1.20 meters long. The fibers are a shiny whitish-green color and smell like watermelon. Some ixtleros claim that working with the fibers causes kidney and lung problems.

The maximum price for fiber in San Miguel Cuyutlán is 200 Mexican pesos per kg, so the price for raw material for one rope alone is 1000 pesos. If the fiber from the state of Mexico costs between 50 and 70 pesos, the cost of a lariat is $50 \%$ less. In a working day 
one ixtlero harvests and prepares 1.5 to $2 \mathrm{Kg}$ and approximately $1 \mathrm{~kg}$ is obtained from 6 leaves. A rope length 30 brazadas (about $28-30 \mathrm{~m}$ ) needs from 4.5 to $5 \mathrm{~kg}$ of fiber.

Ixtleros and lariat makers mentioned that changes in land use, deforestation, grazing, forest fires, and overexploitation of the resource by new and young ixtleros with little knowledge affected $A$. inaequidens repopulation. Despite their opinionated responses, each interviewee mentioned that they could not say with any certainty which of the circumstances was more responsible for the decrease in agave. Further, they explained that until a community standards compliance agreement is made, negative environmental changes will likely continue in Cerro Viejo. They also expressed regret regarding their potential role for not engaging in sustainable practices and remained concerned about having to make their lariats with substandard agave fiber.

On our visits to wild $A$. inaequidens populations, we recorded diseases such as core rot (due to Erwinia spp. pathogens) and insect pests such as the agave weevil (Scyphophorus acupunctatus Gyllenhal Curculionidae). Although hunting was not mentioned, it could be a factor affecting populations, as the flower stalks are picked by hunters to attract deer, who like to eat them. With the decrease in A. inaequidens populations in Cerro Viejo, rope makers have begun to partially substitute fibers from Coatepec Harinas near Mexico City. Using information they provided, we calculated that the fibers bought in Coatepec Harinas represent $80 \%$ of the total fibers needed to replace those from Cerro Viejo. More long-term studies are needed to monitor newly germinated, young, and adult plants.

\section{Rope Production in San Miguel Cuyutlán}

The production and value-added chain of rope crafting in Jalisco begins with the quality of the raw material obtained from $A$. inaequidens and continues with the work, entirely by hand, of the artisan, ending with the consumer (the charro) who gives the rope the final touch, or "tames" it. There are no records of total rope production, but we estimate that each workshop, which is comprised of anywhere from three to twelve employees, works 6 months of the year (24 weeks), making 5 ropes a week for a total of 120 ropes per year. We calculate the annual production of one workshop to be 24 ropes with a total of 600 ropes for the five workshops in the region.

\section{Rope Quality and Reputation}

The flexibility, lifetime, resistance to friction, tempering (ability to retain shape), weight and color of the San
Miguel Cuyutlán-produced ropes help charros to better execute the skills needed to earn more points during competitions. Stiff, heavy ropes are less flexible and more likely to crack, making them less suitable for executing the figures of the floreo. Points are deducted from the charros' score if the rope breaks. A good lariat will withstand the friction, heating and stretching that it is subjected to in charrería events. The quality and lifetime of a rope are dependent on the material it is made of and the process of making it, maintenance, the event it is used for, and humidity and moisture levels. A rope will last a charro between four months to four years with the average being one year.

Charros attribute the quality of a lariat to the material (ixtle) and the process by which it is made. A rope's propensity to dry out, and therefore to weaken and crack or break, is considered to result from the spinning technique and the length of the fibers. If resistant yarns of uniform thickness are formed in the rope-making process, the rope will be more durable. For this reason, the shorter fibers of other agaves such as sisal, henequen, and lechuguilla are not suitable.

Rope artisans sign their work by an industrial color; during the process the first meter of the rope is dyed in a pattern using yellow, red or black, or a combination of colors. The price of a rope depends on its quality, length, and the process used to make it varying from 125 to 250 US dollars. The demand for charro ropes was estimated conservatively from the number of ropes used per year per team in a national championship competition. In one year, there are an average of 150 charrería teams, and twenty ropes per team, hence a demand of 3000 ropes in four years and an annual demand of 750 ropes. There are no recorded data for this industry, but using our information, we assume a total annual value of 112,500 US dollars (150 USD per unit).

According to the charros we interviewed, the best ropes in Mexico are crafted in San Miguel Cuyutlán, and the second-best are those made in Coatepec Harinas. Charro associations in Jalisco appraise the ropes from different regions of Mexico as follows:

- Ropes tend to be too dry and do not last long (Oaxaca and northern Mexico)

- Ropes are not tight enough and deform with use (Central Mexico).

- Coatepec Harinas ropes are heavier and tend to lose their form.

In summary, the quality of the fiber and the local expertise in San Miguel Cuyutlán of hand spinning and 
other traditional knowledge are what make this rope the best.

\section{Discussion and Conclusion}

Although much has been written about charrería and charro culture, little is known about the handicrafts associated with these traditions. Even less is known about the role of Agave inaequidens as a source of charro rope raw material or the factors that explain the recent decrease of its population. This study fills in some of these gaps by documenting the local use and cultural and economic value of $A$. inaequidens in San Miguel Cuyutlan and by addressing the possible causes of the decrease in the wild population. To understand the importance of fiber from wild agaves, we examined the regional cluster of rope making in charrería and the traditional knowledge which is widely recognized as an important part of Mexico's cultural heritage.

As our interviews illustrate, rope artisans value their heritage and recognize the importance of the traditional knowledge that they zealously maintain with the unwritten details of the process. One unresolved matter that concerns the craftsmen is the safety of their intellectual property, and the possibility that their skills might eventually be adopted in China, which could undermine the already tenuous sustainable circumstances of their trade. Many of the artisans stated that they were interested in registering a collective trademark, but they could not afford the fees associated with such an undertaking. Other concerns included the high rate of emigration to the United States, which resulted in fewer young men entering the seasonal rope crafting profession as apprentices. Rope crafting not only provides added income in the dry season when the demand for farm labor is low in the region, but also helps the men maintain their roots in the region.

We also found that, $A$. salmiana fibers from central Mexico were not a good quality substitute for $A$. inaequidens fibers from the Cerro Viejo Mountains. During the 2008-2009 global financial crisis, the demand for lariats decreased slightly. As a consequence, pressure on the local agave population did not increase, but concerns about the supply continued, as dependence on raw materials from outside of Cerro Viejo remained consistent.

The lariat artisans were adamant that partial substitution for local fibers has a limit. Too great a proportion of non-local fiber will decrease the overall quality of their lariats. In the long run, this could have a negative effect on their reputation and on the price of the ropes. The traditional knowledge held by agave fiber harvesters could be used to set community standards which might lead to local environmental governance as a first step towards a sustainable management plan. A similar route has been taken in the south of Mexico with $A$. cupreata mezcal production, where the model looks toward reforestation and not commercial plantations (Larson, Valenzuela-Zapata, and Illsley 2007).

We suggest that systematized work with stakeholders is needed to solve the overexploitation problem. The training and bringing together of the various social actors should integrate traditional ecological knowledge to promote sustainable extraction. In addition, development agreements with charrería associations should be fostered by local governments, and more research is needed to better understand the potential for other collaborative projects. Specifically, more technical studies are needed in demographic, biological, ecological, hydrological, ethno-ecological areas of analysis, and on the potential use of intellectual property initiatives for rural artisans. Finally, interdisciplinary researchers should engage in more rural, participative, communal studies to gain greater insight into what the artisans and other stakeholders see as the problems affecting their environment instead of first turning to biotechnological solution tools that tend to reduce biological diversity with in vitro plantations (personal communication, Dr. Juan Florencio Gómez 2010).

\section{Acknowledgements}

This study was made possible by the valuable information provided by the ixtleros, rope crafters, and charros of Jalisco and the state of Mexico. We would like to thank Cynthia Fowler and Gwyn Fisher for their translation assistance. We are also grateful for the critical feedback from the anonymous referees and the valuable comments from Dr. Alejandro de Avila.

\section{References Cited}

Dean, Frank and Rodriguez Ignacio, 2003. Trick and Fancy Roping in the Charro Style. Wild West Arts Club, Las Vegas, NV.

García-Mendoza, A. 2002. Distribution of the Genus Agave (Agavaceae) and this Endemic Species in Mexico. Cactus and Succulent Journal 74:177-187.

García-Mendoza, A. 2004. Agavaceas. In Biodiversidad de Oaxaca. Instituto de Biología, edited by J. García, Abisaí, M. J. Ordoñez and M. Briones-Salas, pp. 159169. UNAM-Fundo Oaxaqueño para la Conservacion de la Naturaleza-World Wildlife Fund, Mexico.

Garcia-Moya E. and C. Ayala-Sosa. 2007. La Lechuguilla: del Rescate de un Recurso? In Lo 
Ancestral hay Futuro: del Tequila, los Mezcales y Otros Agaves, edited by S. P. Colunga-García Marín, Luis Eguiarte, A. Larqué-Saavedra and D. ZizumboVillarreal, pp. 355-365. Cicy, Mérida, Yucatán, México. González, V. L. M. 1986. Contribución al Conocimiento del Género Quercus (Fagaceae) en el Estado de Jalisco. Colección Flora de Jalisco, Universidad de Guadalajara, Mexico.

Gentry, H. S. 1982. Agaves of Continental North America. University of Arizona Press, Tucson.

Islas Escárcega, Leovilgildo. 1992. Diccionario y Refranero Charro. Edamex, México.

Larson, J., A. G. Valenzuela-Zapata, and C. Illsley. 2007. Del Whisky Escocés al Mezcal: Diferenciación y Etiquetado, Desarrollo y Conservación. In Lo Ancestral hay Futuro: del Tequila, los Mezcales y Otros Agaves, edited by S. P. Colunga-García Marín, Luis Eguiarte, A. Larqué-Saavedr,a and D. ZizumboVillarreal, pp. 213-228. Cicy, Mérida, Yucatán, México.

LeCompte, M.L. 1985. The Hispanic Influence on the History of the Rodeo, 1823-1922. Journal of Sport History 12(1):21-38.

Nájera-Ramírez, O. 1994. Engendering Nationalism: Identity, Discourse, and the Mexican Charro. Anthropological Quarterly 67(1):1-14.

Nobel, P. S. 2010. Desert Wisdom/Agaves and Cacti: CO2, Water, Climate Change. iUniverse, Inc., New York.

Palomar Verea, C. 2004. El Papel de la Charrería Como Fenómeno Cultural en la Construcción del Occidente de México. Revista Eruopea de Estudios Latinomericanos y del Caribe. Available at http://www.cedla.uva.nl/50_publications/pdf/revista/ 76RevistaEuropea/76Palomar.pdf. Accessed on June 21, 2011.

Reyes-Agüero, J. A., R. J. R. Aguirre, and B. Peña. 2000. Aprovechamiento de Agave Lechuguilla Torrey. Boletin de la Sociedad Botanica de Mexico 67:75-88.

Saumade, Frédéric 2008. Maçatl. les Transformations Mexicaines des Jeux Taurins. Presses Universitaires de Bordeaux, France.

Valenzuela, Z. A G. 2011. A New Agenda for Blue Agave Landraces: Food, Energy and Tequila. GCB Bionergy 3(1):15-24.

Valenzuela, Z. A G. and G. P. Nabhan. 2004. Tequila. A Natural and Cultural History. University of Arizona Press, Tucson.

Valenzuela, Z. A. G., A. Regalado, M. Mizoguchi. 2008. Influencia Asiática en la Producción de Mezcal en la
Costa de Jalisco. El caso de la Raicilla. México y la Cuenca del Pacífico 11(32):81-116.

Vázquez- García, J. A. et al. 2007. Taxonomía del Género Agave en el Occidente de México: Una Panorámica Preliminar. In Los Agaves del Occidente de México, edited by J. A. Vázquez-García, M.J. Cházaro, G. Hernández, V. E. Flores, and Y. L. Vargas-Rodriguez, pp. 38-82. Universidad de Guadalajara CUCBA-CUCSH, Mexico.

Yetman, D. and T. R. Van Devender. 2002. Mayo Ethnobotany: Land, History, and Traditional Knowledge in Northwest Mexico. University of California Press, Berkeley.

\section{Biosketches}

Ana G. Valenzuela Zapata is Professor at University of Guadalajara CUCIENEGA and Signo Tequila President charged in agave landraces conservation.

Irma López Muraira is Professor at Instituto Tecnológico de Tlajomulco in Jalisco.

Marie Sarita Gaytan is an Assistant Professor Sociology and Gender Studies at the University of Utah.

\footnotetext{
${ }^{1}$ We will have more information in six years (2017) when the first plants are ready for harvest.

${ }^{2}$ Approximately 40 high quality video segments are now available for public viewing on YouTube.

3 For this paper we assume it is the same species, however we cannot be sure if there are actually two subspecies without further studies and flowering samples. That is, all we can state scientifically is that there may be two subspecies or intraspecific categories; however it could merely be a symptom of the domestication of plants selected from the same species.

${ }^{4}$ Tripping of horses has been voluntarily banned by official charro organizations since 1995. If a charro pulls the rope in an attempt to trip the horse, he is expelled for one year and fined $\$ 350$ dollars. The individual is also subject to state laws and regulations where the practice is illegal.
} 